\title{
Effect of Ascorbic Acid on Hydroxylase Activity
}

\section{Stimulation of Tyrosine Hydroxylase and Tryptophan-5- Hydroxylase Activities by Ascorbic Acid}

\author{
Yoko Nakashima, Ryokuero Suzue, Hiroo Sanada \\ AND SHOJI KAWADA ${ }^{1}$
}

\author{
National Institute of Nutrition, 1 Toyamacho, \\ Shinjuku-ku, Tokyo (Post No. 162)
}

(Received August 24, 1970)

\begin{abstract}
The effect of ascorbic acid on the hydroxylase and dehydrogenase activities was studied in vivo to clarify its role in the biological oxidation. Tyrosine hydroxylase and tryptophan-5-hydroxylase which require 2-amino-4-hydroxy-6,7dimethyltetrahydropteridine $\left(\mathrm{DMPH}_{4}\right), \mathrm{NADP}$ and molecular oxygen were investigated with the non-scorbutic and scorbutic guinea pigs. Several dehydrogenases such as glucose-6-phosphate dehydrogenase, isocitrate dehydrogenase and malic enzyme, which require no molecular oxygen but NADP, were also studied by comparing the activities in the non-scorbutic guinea pig with those in the scorbutic guinea pig. The results indicated that the activities of tyrosine hydroxylase and tryptophan-5-hydroxylase of the adrenal gland, liver and brain of the nonscorbutic guinea pig were higher than the values found in the scorbutic guinea pig, although no significant change in the activity of dehydrogenase was observed in the tissues of the non-scorbutic and scorbutic guinea pigs.
\end{abstract}

It has been known that the most prominent property of ascorbic acid is to be easily oxidized and reversibly reduced, and that the essential function of ascorbic acid might be related with the biological oxidation. Studies were undertaken to explore the effect of ascorbic acid on the levels of hydroxylase and dehydrogenase as typical enzymes concerned with the biological oxidation.

There are some reports on the changes of activities of hydroxylase and dehydrogenase by ascorbic acid. Robertson (1) has indicated that during the formation of collagen ascorbic acid may stimulate the hydroxylation of proline. Hofmann et al. (2) and Staudinger (3) have suggested that ascorbic acid is involved in the hydroxylation of corticosteroid in adrenal homogenate. Despite of these investigations, however, the effect of ascorbic acid on the activities of tyrosine hydroxylase and tryptophan-5-hydroxylase has not been clarified yet.

The present paper reports the effect of ascorbic acid on the activities of tyrosine hydroxylase and tryptophan-5-hydroxylase (1. 99.1.4) as representative hydroxylases, and on the activities of glucose-6-phosphate dehydrogenase (1.1.1.49), isocitrate dehydrogenase (1. 1.1.42) and malic enzyme (1.1.1.40) as representative dehydrogenases. The two hydroxylases require molecular oxygen, $\mathrm{DMPH}_{4}$ and NADP. On the other hand, these dehydrogenases require only NADP as coenzyme. The results obtained here indicate that ascorbic acid does not stimulate the activities of dehydrogenases in vivo but does the activities of hydroxylases.

\footnotetext{
1 中嶋洋子, 鈴江緑衣郎, 真田宏夫, 河田正治.
} 


\section{EXPERIMENTAL}

\section{Materials}

L-Tyrosine-3, $5{ }^{3} \mathrm{H} \quad(35.3 \mathrm{Ci}$ per mmole) was obtained from Radiochemical Centre, Amersham, England. It was purified as follows: to remove labile ${ }^{3} \mathrm{H}$, methanol (approximately $5 \mathrm{ml}$ ) was mixed with $1 \mathrm{mCi}$ of L-tyrosine- $3,{ }^{-3} \mathrm{H}$ and the mixture was evaporated in vacuo to dryness. This treatment was repeated several times, and the final residue was dissolved in $1 \mathrm{ml}$ of distilled water and stored at $-20^{\circ}$. $\mathrm{DMPH}_{4}$ was purchased from Calbiochem. Glucose-6-phosphate and NADP were purchased from Sigma. All other chemicals were obtained from commercial sources.

\section{Ascorbic Acid Deficient Diet}

The ascorbic acid deficient diet consisted of the following composition: protein, $24 \%$; carbohydrate, $56 \%$; fat, $3.5 \%$; crude fiber, $4.5 \%$; ash, $6.0 \%$ and water, $6.0 \%$. Vitamin mixture was prepared as follows (per kilogram of diet), vitamin A, 10,000 IU; vitamin $\mathrm{D}_{3}, 2,000 \mathrm{IU}$; vitamin $\mathrm{E}, 10 \mathrm{mg}$; thiamine, 5.6 $\mathrm{mg}$; riboflavin, $10 \mathrm{mg}$; pyridoxine, $4 \mathrm{mg}$; vitamin $\mathrm{B}_{12}$, $0.002 \mathrm{mg}$; calcium pantothenate, $26 \mathrm{mg}$; niacin, $44 \mathrm{mg}$; folic acid $0.8 \mathrm{mg}$; and choline chloride, $400 \mathrm{mg}$.

3. Animals and Preparation of Homogenate

Male guinea pigs, weighing about $300 \mathrm{~g}$, were fed ascorbic acid deficient diet for 18 days. The animals were separated into two groups; one group was administered $200 \mathrm{mg}$ of ascorbic acid per day during the last three days by intraperitoneal injection in a volume of $2 \mathrm{ml}$ (the non-scorbutic group); and the other was given the same volume of $0.9 \%$ $\mathrm{NaCl}$ solution (the scorbutic group). Thses groups were pair fed. Twenty-four hours after the last administration, they were sacrificed by decapitation and the adrenal gland, liver and brain were removed immediately. The tissues were weighed and then homogenized with 2 volumes of ice cold $0.32 \mathrm{M}$ sucrose using a Potter-Elvehjem homogenizer.

\section{Assay of Tyrosine Hydroxylase}

The activity of tyrosine hydroxylase was assayed by measuring the rate of release of tritium from Ltyrosine $3,{ }^{-3} \mathrm{H}$ into water as described by Nagatsu et al. (4). The incubation mixture contained sodium acetate $(\mathrm{pH} 6.0), 200 \mu$ moles; potassium phosphate $(\mathrm{pH} 6.0), 10 \mu$ moles; $\mathrm{DMPH}_{4}, 0.5 \mu$ mole; 2-mercaptoethanol, $50 \mu$ moles $; \mathrm{FeSO}_{4}, 0.5 \mu$ mole $; 3,5{ }^{3} \mathrm{H}$-tyrosine, $0.2 \mu$ mole $(150,000 \mathrm{cpm})$ and enzyme $(5$ to $10 \mathrm{mg}$ of protein), in a final volume of $1.0 \mathrm{ml}$. Incubation was carried out for $30 \mathrm{~min}$ at $38^{\circ}$. The reaction was terminated by the addition of $0.05 \mathrm{ml}$ of glacial acetic acid. The tube was centrifuged, and the entire supernatant solution was transferred to a column $(0.5 \times 3.0 \mathrm{~cm})$ of Dowex $50-\mathrm{H}^{+}$rinsed with $5.0 \mathrm{ml}$ of water. The effluent was collected, an $1.0 \mathrm{ml}$ aliquot of which was transferred to a scintillation vial containing $10 \mathrm{ml}$ of Bray's solution (5). Radioactivity was measured in a liquid scintillation spectrometer.

\section{Assay of Tryptophan-5-Hydroxylase}

The activity of tryptophan-5-hydroxylase was assayed by the modification of the procedure described by Ichiyama et al. (6). The enzyme assay was performed in a Warburg flask containing Tris-acetate buffer ( $\mathrm{pH} 8.1$ ), $50 \mu$ moles; L-tryptophan- $1{ }^{14} \mathrm{C}, 11.3$ $\mathrm{m} \mu$ moles $(80,000 \mathrm{cpm})$ and $0.2 \mathrm{ml}$ of homogenate in a final volume of $0.5 \mathrm{ml}$. Each vessel was incubated for $60 \mathrm{~min}$ at $37^{\circ}$. The reaction was terminated by the addition of $0.5 \mathrm{ml}$ of $6 \%$ perchloric acid. ${ }^{14} \mathrm{CO}_{2}$ evolved from L-tryptophan- $1-{ }^{14} \mathrm{C}$ was trapped with hyamine and its radioactivity was measured by a liquid scintillation spectrometer.

\section{Assay of Dehydrogenases}

The activity of glucose- 6 -phosphate dehydrogenase was calculated from the initial rate of NADPH increase measured at $340 \mathrm{~m} \mu$ in the test system described by Warburg and Christian (7). Malic enzyme was assayed essentially according to the method of Ochoa (8). The activity of isocitrate dehydrogenase was measured by the appearance of NADPH, determined by the increase in optical density at $340 \mathrm{~m} \mu$ as described by Ochoa (9). The assays of these dehydrogenases were made in a cuvett of ,1-cm path length; all components except enzyme were brought to temperature equilibrium at $25^{\circ}$, and then the reaction was started by the addition of enzyme.

Protein was determined according to Lowry et al. (10). The concentration of ascorbic acid in the tissues was estimated by phenylhydrazine method (11).

\section{RESUlTs}

\section{Concentration of Ascorbic Acid in the} Tissues of Scorbutic and Non-scorbutic Guinea Pigs

The concentration of ascorbic acid was measured in the liver, adrenal gland and brain of the non-scorbutic and scorbutic guinea pigs. In the non-scorbutic guinea pig, the ascorbic acid concentration in adrenal gland was higher than that of other tissues, whereas in scurvy the concentration of ascorbic acid was highest 
TABLE 1

Ascorbic acid content in the tissues of scorbutic and non-scorbutic guinea pigs

\begin{tabular}{lcc}
\hline & Non-scorbutic & Scorbutic \\
\hline Liver & 0.255 & 0.006 \\
Adrenal gland & 1.105 & 0.015 \\
Brain & 0.266 & 0.079 \\
\hline
\end{tabular}

All values are expressed as $\mathrm{mg} / \mathrm{g}$ tissue.

The scorbutic guinea pigs were fed ascorbic acid deficient diet for two weeks.

in the brain, as indicated in Table 1 . The concentration of ascorbic acid in liver, adrenal gland and brain of the scorbutic guinea pig was lower with high significance than that of the non-scorbutic guinea pig.

2. Effect of Ascorbic Acid on Dehydrogenase Activities

Table 2 represents the activities of glucose-6-P dehydrogenase, isocitrate dehydrogcnase and malic enzyme of the non-scorbutic and scorbutic guinea pigs. The results indicated that there was no significant difference

TABLE 2

Effect of ascorbic acid on dehydrogenase activity

\begin{tabular}{|c|c|c|c|c|}
\hline & & & Non-scorbutic & Scorbutic \\
\hline \multirow{3}{*}{$\begin{array}{l}\text { Glucose-6- } \\
\text { phosphate } \\
\text { dehydro- } \\
\text { genase }\end{array}$} & $\begin{array}{l}\text { Adrenal } \\
\text { gland }\end{array}$ & $\begin{array}{l}\text { S.A. } \\
\text { T.A. }\end{array}$ & $\begin{array}{c}22.1 \pm 1.8 \\
524 \pm 101\end{array}$ & $\begin{array}{c}22.3 \pm 3.1 \\
503 \pm 48\end{array}$ \\
\hline & Liver & $\begin{array}{l}\text { S.A. } \\
\text { T.A. }\end{array}$ & $\begin{array}{c}1.3 \pm 0.1 \\
2,577 \pm 533\end{array}$ & $\begin{array}{r}1.1 \pm 0.2 \\
2,610 \pm 289\end{array}$ \\
\hline & Brain & $\begin{array}{l}\text { S.A. } \\
\text { T.A. }\end{array}$ & $\begin{array}{c}6.9 \pm 0.1 \\
881 \pm 46\end{array}$ & $\begin{array}{l}7.4 \pm 0.2 \\
866 \pm 23\end{array}$ \\
\hline \multirow{3}{*}{$\begin{array}{l}\text { Iso- } \\
\text { citrate } \\
\text { dehydro- } \\
\text { genase }\end{array}$} & $\begin{array}{l}\text { Adrenal } \\
\text { gland }\end{array}$ & $\begin{array}{l}\text { S.A. } \\
\text { T.A. }\end{array}$ & $\begin{array}{c}31.3 \pm 3.1 \\
738 \pm 61\end{array}$ & $\begin{array}{c}31.0 \pm 0.7 \\
779 \pm 46\end{array}$ \\
\hline & Heart & $\begin{array}{l}\text { S.A. } \\
\text { T.A. }\end{array}$ & $\begin{array}{c}115.2 \pm 2.6 \\
36,000 \pm 3,700\end{array}$ & $\begin{array}{c}119.3 \pm 3.8 \\
39,000 \pm 3,300\end{array}$ \\
\hline & Brain & $\begin{array}{l}\text { S.A. } \\
\text { T.A. }\end{array}$ & $\begin{array}{c}5.4 \pm 0.4 \\
660 \pm 41\end{array}$ & $\begin{array}{c}5.4 \pm 0.7 \\
644 \pm 78\end{array}$ \\
\hline \multirow{3}{*}{$\begin{array}{l}\text { Malic } \\
\text { enzyme }\end{array}$} & Adrenal & $\begin{array}{l}\text { S.A. } \\
\text { T.A. }\end{array}$ & $\begin{array}{l}7.2 \pm 0.2 \\
176 \pm 44\end{array}$ & $\begin{array}{c}7.8 \pm 0.4 \\
172 \pm 35\end{array}$ \\
\hline & Liver & $\begin{array}{l}\text { S.A. } \\
\text { T.A. }\end{array}$ & $\begin{array}{c}0.48 \pm 0.06 \\
918 \pm 109\end{array}$ & $\begin{array}{l}0.36 \pm 0.01 \\
915 \pm 12\end{array}$ \\
\hline & Brain & $\begin{array}{l}\text { S.A. } \\
\text { T.A. }\end{array}$ & $\begin{array}{c}2.3 \pm 0.2 \\
136 \pm 27\end{array}$ & $\begin{array}{c}2.3 \pm 0.1 \\
130 \pm 10\end{array}$ \\
\hline
\end{tabular}

S.A. (specific activity) was defined as the amount catalyzing the production of NADPH ( $\mathrm{m} \mu$ moles) in $1 \mathrm{~min}$ per $\mathrm{mg}$ of protein. T.A. (total activity) was defined as the amount catalyzing the production of NADPH (m $\mu$ moles) in $1 \mathrm{~min}$ per whole tissue. Values represent the mean of 3 guinea pigs \pm S.E.M. between the non-scorbutic and scorbutic guinea pigs in the specific activity as well as the total activity of the glucose-6-P dehydrogenase in the adrenal gland, liver and brain. No significant difference of the malic enzyme activity in adrenal gland, liver and brain was observed between the non-scorbutic and scorbutic guinea pigs. Table 2 also shows the specific activities and total activities of isocitrate dehydrogenase in adrenal gland, heart and brain of the nonscorbutic and scorbutic guinea pigs. Again, no difference in the isocitrate dehydrogenase activity was observed in the non-scorbutic and scorbutic guinea pigs. These results suggest that ascorbic acid does not affect the activities of dehydrogenases that require NADP but not molecular oxygen.

\section{Effect of Ascorbic Acid on Hydroxyl-} ase Activity

The data given in Table 3 show the effect of ascorbic acid on the activity of tyrosine hydroxylase in adrenal gland, liver and brain. The tyrosine hydroxylase activity of the nonscorbutic guinea pig was 2 fold higher than that of the scorbutic guinea pig in adrenal gland, 3 fold higher in liver and 4 fold higher in brain.

Table 4 represents the effect of ascorbic acid on the activity of brain tryptophan-5hydroxylase. The rate of serotonin formation in the non-scorbutic guinea pig was 0.269 $\mathrm{m} \mu$ mole per hour per gram brain, whereas the

TABLE 3

Effect of ascorbic acid on tyrosine hydroxylase activity

\begin{tabular}{llcc}
\hline & & Non-scorbutic & Scorbutic \\
\hline \multirow{2}{*}{ Adrenal gland } & S.A. & $3.5 \pm 0.2$ & $1.8 \pm 0.3$ \\
& T.A. & $133.9 \pm 26$ & $77.0 \pm 14.0$ \\
\multirow{2}{*}{ Liver } & S.A. & $0.14 \pm 0.01$ & $0.05 \pm 0.009$ \\
& T.A. & $364.2 \pm 73.0$ & $109.8 \pm 52.0$ \\
Brain & S.A. & $0.82 \pm 0.10$ & $0.21 \pm 0.05$ \\
& T.A. & $246.4 \pm 92.0$ & $60.4 \pm 21.0$ \\
\hline
\end{tabular}

S.A. (specific activity) was defined as the activity of enzyme which catalyzes the release of ${ }^{3} \mathrm{H}$ from ${ }^{3} \mathrm{H}$-tyrosine equivalent to the formation of $1 \mathrm{~m} \mu$ mole of dopa in $30 \mathrm{~min}$ per $\mathrm{mg}$ of protein. T.A. Itotal activity) was defined as the activity of the enzyme which catalyzes the release of ${ }^{3} \mathrm{H}$ from ${ }^{3} \mathrm{H}$-tyrosine in $30 \mathrm{~min}$ per whole tissue. Values represent the mean of 9 guinea pigs \pm S. E.M. 
TABLE 4

Effect of ascorbic acid on brain tryptophan-5. hydroxylase activity

\begin{tabular}{ll}
\hline Non-scorbutic & \multicolumn{1}{c}{ Scorbutic } \\
\hline $0.269 \pm 0.035$ & $0.169 \pm 0.013$ \\
$159(\%)$ & $100(\%)$
\end{tabular}

Enzyme activity was defined as the amount which synthesized $1 \mathrm{~m} \mu$ mole of serotonin in hour per gram of brain. The values were calculated on gram of brain and were expressed relative increase to the scorbutic group.

rate in the scorbutic guinea pig was 0.169 $\mathrm{m} \mu$ mole. There was $59 \%$ increase in the brain tryptophan-5-hydroxylase activity of the non-scorbutic guinea pig compared with the scorbutic guinea pig.

Fig. 1 summarizes the effect of ascorbic acid on hydroxylase and dehydrogenase activities in brain. These results suggest that ascorbic acid is involved in some biological oxidation reactions, and that the administration of ascorbic acid does not affect the activity of dehydrogenase which requires only NADP as coenzyme, but stimulates the ac-
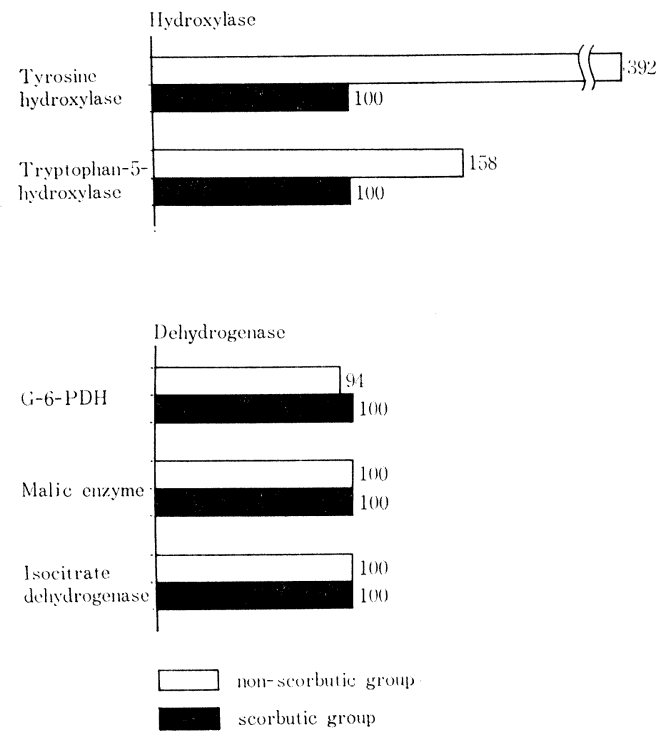

FIG. 1 Effect of ascorbic acid on brain hydroxylase and dehydrogenase activity

The values were caluculated on specific activity and were expressed relative increase to the scorbutic group. tivity of hydroxylase which requires molecular oxygen, $\mathrm{DMPH}_{4}$ and NADP.

In order to investigate whether this effect of ascorbic acid on tyrosind hydroxylase and tryptophan-5-hydroxylase activity is direct or not, we performed the following experiment in vitro. When ascorbic acid, $1 \times 10^{-6} \mathrm{M}$ to $1 \times$ $10^{-4} \mathrm{M}$ was added to the homogenate of adrenal gland of the scorbutic guinea pig, no remarkable stimulation of tyrosine hydroxylase and of tryptophan-5-hydroxylase activities were observed.

\section{Discussion}

There were some reports on the changes of the enzyme activity involved in the biological oxidation by administration of ascorbic acid. Banerjee (12) reported that the activities of succinate, malate and lactate dehydrogenases moderately decreased in scurvy, whereas no change in the activity of isocitrate dehydrogenase which requires NADP as coenzyme was observed in normal and scorbutic guinea pigs.

Gould and Woessner (13) suggested that in ascorbic acid deficiency, the hydroxylation of proline was blocked and a protein that resembled collagen but contained no hydroxyproline accumulated. Kresten et al. (14) indicated that the rate of hydroxylation of deoxycorticosterone was increased by ascorbic acid. Staudinger (15) showed that the hydroxylation of compounds such as acetoanilide, was stimulated by ascorbic acid in the presence of $\mathrm{NADH}$ and rat liver microsomal fraction.

The experiment reported here showed that the activity of hydroxylase such as tyrosine hydroxylase and tryptophan-5-hydroxylase was found to decrease in scurvy. Thus, this change might be due to the following causes. 1) Directly ascorbic acid activates the hydroxylase activity. 2) Ascorbic acid affects the activation of low molecular coenzyme or metal ion such as $\mathrm{Fe}^{2+}$. 3) Ascorbic acid reflects on increase in the amount of protein moiety of the enzyme, or 4) other protein such as cytochrome $\mathrm{P}-450(16,17)$ is involved in enzyme activation. 
When ascorbic acid, $1 \times 10^{-6} \mathrm{M}$ to $1 \times 10^{-4} \mathrm{M}$ was added to the adrenal homogenate of the scorbutic guinea pig, the increase in tyrosine hydroxylase activity was not observed. This result showed that the effect of ascorbic acid on this enzyme system was not direct. Petrack et al. (18) also indicated that partially purified tyrosine hydroxylase did not require ascorbic acid.

Nagatsu et al. (19) and Petrack et al. (18) described that $\mathrm{Fe}^{2+}$ stimulated the tyrosine hydroxylase activity in vitro and that the higher activity and the greater stability were obtained when $\mathrm{Fe}^{2+}, \mathrm{DMPH}_{4}$ and mercaptoethanol were added. Therefore, in all experiments, sufficient amount of $\mathrm{Fe}^{2+}, \mathrm{DMPH}_{4}$ and mercaptoethanol were added to the reaction mixtures. It is clear that the stimulation of enzyme activity after administration of ascorbic acid is not due to $\mathrm{Fe}^{2+}$ or coenzýme such as $\mathrm{DMPH}_{4}$.

And also it was considered that the stimulatory effect of ascorbic acid on the hydroxylase activity might be due to an increase in the amount of the protein moiety of the enzyme or other protein involved in enzyme activation. Further studies are necessary to clarify the role of ascorbic acid in the stimulation of hydroxylase activity in vivo.

In the next paper, we will investigate whether protein synthesis is increased by the administration of ascorbic acid in the scorbutic guinea pig.

\section{ACKNOWLEDgEMENT}

We gratefully acknowledge the excellent technical assistance of Miss Haruyo Yamazaki.

\section{REFERENCES}

1. Robertson, W., Ann. N.Y. Acad. Sci., 92, 159 (1961).

2. Hofmann, H., and Staudinger, H., Arzneimittel. Forsch., 1, 416 (1951).

3. Staudinger, H., Proc. 4th Internat. Congr. Bio. chem., Vienna, 1958 vol. 4, p. 74, Pergamon Press, Oxford, (1959).

4. Nagatsu, T., Levitt, M., and Udenfriend, S., Anal. Biochem., 9, 122 (1964).

5. Bray, G. A., Anal. Biochem., 1, 279 (1960).

6. Ichiyama, A., Nakamura, S., Nishizuka, Y., and Hayaishi, O., in S. Garattini and P.A. Shore (Editors), Advance in pharmacology, Academic Press, New York, 6A, p. 5 (1968).

7. Warburg, O., and Christian, W., Biochem. Z., 287, 291 (1936).

8. Ochoa, S., Mehler, A. H., and Kornberg, A., $J$. Biol. Chem., 174, 979 (1948).

9. Ochoa, S., J. Biol. Chem., 174, 133 (1948).

10. Lowry, O.H., Rosenburgh, N. J., Farr, A.L., and Randall, R. J., J. Biol. Chem., 193, 265 (1951).

11. Roe, J. H., Mills, M.B., Oesterling, M. J., and Damson, C. M., J. Biol. Chem., 174, 201 (1948).

12. Banerjee, S., Biswas, D. K., and Singh. H. D., J. Biol. Chem., 234, 405 (1958).

13. Gould, B. S., and Woessner, J. F., J. Biol. Chem., 266, 289 (1957).

14. Kersten, H., Leonhaüster, S., and Staudinger, H., Biochem. Biophys. Acta, 29, 350 (1958).

15. Staudinger, H., Krisch, K., and Leonhaüster, S., Ann. N. Y. Acad. Sci., 92, 195 (1961).

16. Lu, A. Y. H., Junk, K. W., and Coon. M. J., J. Biol. Chem., 244, 3714 (1969).

17. Kimura, T., and Suzuki, K., J. Biol. Chem., 242, 485 (1967).

18. Petrack, B., Sheppy, F., and Fetzer, V., J. Biol. Chem., 243, 743 (1968).

19. Nagatsu, T., Levitt, M., and Udenfriend, S., J. Biol. Chem., 239, 2910 (1964). 